\title{
Sports Participation and Physical Personality Variable of Students in Secondary Schools in Central Senatorial District of Cross River State, Nigeria
}

\author{
Odok, E.A., Edim, M.E. ${ }^{1}$, Ekuri, P.K. \\ Department of Human Kinetics \& Health Education \\ Faculty of Education, University of Calabar, Calabar - Nigeria
}

\begin{abstract}
The main thrust of this study was to investigate sports participation and physical personality variable of students in secondary schools in Central Senatorial District of Cross River State, Nigeria. To achieve the purpose of this study, one hypothesis was formulated to guide the study. Literature review was carried out according to the variable of the study. Survey research design was adopted for the study. A sample of five hundred (500) respondents was randomly selected for the study. The selection was done through the simple random sampling technique. The questionnaire was the instrument used for data collection. The reliability estimate of the instrument was established through the Cronbach Alpha reliability method. Independent t-test analysis was employed to test the hypothesis under study. The hypothesis was tested at .05 level of significance. The result of the analysis revealed that, there is a significant difference in the physical variables of secondary school students who participate and those who do not participate in sports. Based on the findings of the study, it was recommended that students in secondary schools should participate in sports to avoid sedentary lifestyle and again, the physical education teachers who are the custodians of sports in these schools, should make sure that every student takes active part in sports during training sessions.
\end{abstract}

\section{INTRODUCTION}

Sports have been regarded as an integral part of the society. Archaeological findings indicate that the early man did not only dance to appease his gods, but also threw spears at wild beasts for survival, a skill that can be compared to javelin throw of modern day.It is now known that dancing which provides an excellent forum for social interaction among people, is a sport as well as a part and parcel of physical education programme. The ancient Greeks also danced to appease their gods. In the ancient and modern Olympics, sports have continued to be a major source of entertainment for people. In fact, it is said that the Olympic Games are the greatest events that brings together the largest population of people from different countries of the world (Sage, 2007)

Sports are motor activities which enable an individual to develop and control his physique. It can also be described as activities involving physical exertion and skill in which an individual or team competes against another or for the purpose of entertainment. Nevertheless, the traditional view of sports participation is that, it has a beneficial effect on the social and moral development of children and young people. Sports may have the tendency if well organised to change the entire human personality (whole-man) through active and passive participation. Such components of personality that sports are capable of transforming include: physical, social, moral, mental, and emotional (Agbomi, 2012).

According to Edim (2011), sports can be termed as well organized and institutionalized physical activities with structured programmes governed with rules and regulations. He further stressed that a good sports programme must be geared towards developing a 'whole-man' which is developing physically, socially skillfully, mentally, emotionally and morally individual (which is otherwise known as personality development) that is acceptable in the community and with good health.

Edim, Emeribe and Akah (2008), expressed that it is not an overstatement to remark that of all school subjects put together, sports alone can take a very prominent position in the educational system. Sports if properly harnessed, can contribute about fifty percent (50\%) or more to the educational goals of the society. They said, it is a well known fact that sports and recreation have been fundamental elements of the curricular of institutions throughout history. According to anthropological and historical researchers, physical education and sports are the most ancient subjects

${ }^{1}$ Corresponding Author: edimmoses@yahoo.com 
in humanities. From early to the present time, sports in one form or the other has been promoted by all fields of world civilization. It has received varying degrees of cultural and government emphasis and attention (Oyeniyi, 2001).

Ndu (2007) expressed further that sports is relatively a new co-curricular activity in the African educational system. It is a fact that its western origin in the continent can be traced back to the missionary activities of 1940s. This explains why up to date, the materials and most of the sporting events have been those related to foreign nations. To the layman, sports are referred to as athletic competitions which have to do with running, jumping, throwing, dancing and wrestling. Others see sports as recreational or competitive activities which involves some amount of physical strength or skills. Odigbo (2000) sees sports as a form of education through a well planned programme of physical activities that aims at meeting with maximum development of the whole individual (physically, socially, mentally, morally and emotionally). Therefore, sports is the development of a well integrated individual having a sound mind in a healthy body, who is also socially sound. Homer, a great ancient philosopher recognizes that sporting activities help to build a sound mind in a sound body.

Hans (1999) defined personality as the more or less stable and enduring organisation of a person's character, temperament, intellect, and physique which determines his unique adjustment to the environment.

The word personality as stated by Prasad and Bannergee (1997), and Agbekuru (2000), was derived from the Greek word "persona" which is a type of mask that covers the actor that exerts influence on the persona or mask. Personality is then perceived as the influence which the actor or person leaves on the audience. The viewers could see the mask, but not the real person behind it. Perhaps, this is why the understanding of personality is such a cumbersome exercise. However, Prasad and Bamergee (1997) were of the view that evaluation of the concept of personality includes an individual's own evaluation about himself with other people's perceptions.

The relevance of sports participation to individual's personalitys, society and the nation at large is multi-faceted. The benefits of sports include social, mental, emotional and motor skill development, recreational skills, aesthetic/entertainment role, scholarship, citizenship and patriotism, career development and economic gains (Afuekwe, 1999).

\subsection{Sports Participation and Physical Personality Variable of Students}

According to Uche (2009), physical variables are concerned with the proper development and maintenance of physical fitness. He defined physical fitness as the ability necessary to complete a given task and still have reserve energy for leisure and emergencies. He further said that it aims at achieving maximum functioning of the muscular and circulo-respiratory systems. The outcome of these is expressed in forms of strength, muscular endurance, flexibility, balance, agility, stamina and power. He observed that participation in sports leads to the development of these named components of physical fitness which are necessary ingredients for efficient daily functioning and happy living.

Okplenye (2008), opined that sports participation leads to development of good health, development of body parts and proper bone formation. For instance, some children grow up with malformed bones such as 'knock knee, bow legs' etc. but early exposure to appropriate exercises, sports and diet help to correct such defects. He concluded that the heart is stronger, healthier and pumps blood better, and circulation of blood is faster and smoother because of physical activities.

Without doubt, there is a broader understanding that the distinctive contribution Physical Education andSchool Sports (PESS) makes to a child's education is within the physical domain. The nature of the physical focus of PESS has shifted over time, moving from an initial health-related rationale in the first half of the twentieth century to more performance-related considerations following the Second World War, to concern about the health impact of sedentary behaviours more recently (Gilman, 2001)

French, Perry, Leon, and Fulkerson, (2008) surveyed students' participation in sports in grades seven through ten (708 males and 786 females) in a mostly white, upper-middle class school district in Minnesota. Sports participation was assessed with a 28 -item checklist representing activities of light to vigorous-intensity. Students were asked to check the activities that they performed for 20 minutes or more and indicate one of five choices as to when the activity was last performed (e.g. today, rarely or never). Dietary constructs were assessed with a 25 -item questionnaire for preference (1 through 5) and level of consumption (1 through 5) of various foods representing sweets, salty snacks, fruits and vegetables, and protein entrees. Factor analysis was used to group the activities into leisure sports, conditioning sports and atypical sports (sports played less frequently). Factor analysis was also used to group the 


\section{American Research Journal of Humanities and Social Sciences, Volume 1, Issue 2, April 2015}

ISSN 2378-7031

foods into junk food or empty calories, salty snacks, healthy foods (e.g. fruits and vegetables, yoghurt) and protein entrée (e.g. hamburger). Among both males and females, participation in leisure sports and conditioning sports was found to be correlated with recent healthy food choices $(r=0.26$ to 0.36$)$, and healthy food preferences $(r=0.13$ to $0.20)$. Among females, conditioning sports $(r=-0.10)$ and atypical sports $(r=-0.09)$ were inversely correlated with salty snack preference, while conditioning sports were inversely associated with junk food preference $(\mathrm{r}=-0.10)$. Among males, conditioning sports was associated with protein entrée preference $(r=0.11)$.

Baumert, Henderson, and Thompson, (2009) examined the relationship between sports participation and dietary intake in 7179 high school students from a single county in the southern United States. Compared to non-participants, sport participants were significantly more likely to report consuming breakfast, fruits and vegetables and one serving from the dairy food group on a daily basis. They were also less likely to add salt to their foods. No differences were found in reported consumption of red meats, fried foods and snack foods. Among the 14747 US high school students who completed the 1993 Youth Risk Behaviour Surveillance (YRBS), sports participants were more likely to report recent consumption of fruits and vegetables than non-participants. In addition, female sports participants were less likely to report recent consumption of high fat foods than non-participants (Pate, Trost, Levin, Dowda, 2000).

Pate, Heath, Dowda, and Trost, (2006) analysed data from the National Youth Risk Behaviour Surveillance (YRBS) to determine if physically active adolescents were more likely than their low-active counterparts to report consumption of fruit or vegetables on the previous day. After adjustment for age group, sex and race, students who did not eat vegetables on the previous day were almost twice more likely to be low active than students who reported eating at least one serving of vegetables. Among the Hispanic and White subgroups, students who ate no fruit on the previous day were 2.3 and 3.1 times, respectively, more likely to be low active than those who ate one or more serving of fruit on the previous day.

Aarnold, Kujala, and Kaprio, (2007) surveyed students' participation in sports with 1097 girls and 1014 boys in Finland from 2006-2007. Physical activity behaviour was classified into one of five categories from very active to inactive based on reported frequency and intensity of physical activity performed outside of school. Saturated fat intake was estimated with a single item regarding use of spread on bread. Response choices included: 1) usually nothing; 2) mostly margarine; 3) mostly butter; 4) butter/margarine mixtures; 5) light spread; and 6) other. Results indicated that the highest activity group was significantly more likely to use no spread on their bread than the inactive group. For example, in the very active group, $15.4 \%$ of girls and $5.2 \%$ of boys reported using no spread; whereas among the inactive, only $1.6 \%$ of girls and none of the boys reported using no spread.

\section{METHODOLOGY}

The research design that was used in this study is Survey design. The population of the study was three thousand four hundred and seven (3407) senior secondary school students from the Central Senatorial District of Cross River State, Nigeria. The simple random sampling technique was used to select 500 senior students for the study.

The research instrument used was the structured questionnaire, comprised of 16 items, all on a four Likert scale. In term of validity, some experts in measurement and evaluation and Human Kinetics and Health Education affirmed with $90 \%$ agreement that the entire instrument was suited for measuring what it purported to measure using the Cronbach Alpha reliability test. The reliability index of the entire instrument was found to be 0.86 . face-to-face hand delivery was method was used during the data collection procedure.

All the 500 copies of the questionnaire were retrieved and thus giving $100 \%$ return rate. The following hypothesis was tested in the study.

- There is no significant difference in the physical variable of students who participate in sports and those who do not participate.

\subsection{Result of the Hypothesis}

Table1. Independent t-test analysis of the difference in physical personality variables of secondary school students who participate and those who do not participate in sports $(N=500)$

\begin{tabular}{|l|l|l|l|l|}
\hline Sport participation & N & X & SD & t-value \\
\hline Those who participate & 309 & 18.38 & 1.13 & \\
\hline Those who do not & 191 & 17.54 & 2.01 & $5.29^{*}$ \\
\hline Total & 500 & 18.06 & 1.17 & \\
\hline
\end{tabular}

$*$ Significant at .05 level, $d f=498$, critical $t=1.96$ 


\section{American Research Journal of Humanities and Social Sciences, Volume 1, Issue 2, April 2015 ISSN 2378-7031}

There is no significant difference in the physical variables of secondary school students who participate in sports and those who do not participate. The dependent variable involved in this hypothesis is Physical variables, while the independent variable is sports participation which is categorized into two (those who participate and those who do not participate). Independent t-test analysis was employed to test this hypothesis. The result of the analysis is presented in Table 1.

The result in the above table reveals that the calculated t-value of 5.29 is greater than the critical t-value of 1.96 at .05 level of significance with 498 degrees of freedom. With this result the null hypotheses was rejected. This implies that there is a significant difference in the physical variables of secondary school students who participate in sports and those who do not.

\section{DISCUSSION OF FINDINGS}

The result of this hypothesis revealed that there is a significant difference in the physical variables of secondary school students who participate in sports and those who do not participate.The finding of this hypothesis is in line with the view of Uche (2009) who observed that physical variables is concerned with the proper development and maintenance of physical fitness. He defined physical fitness as the ability necessary to complete a given task and still have reserve energy for leisure and emergencies. He further said that it aims at achieving maximum functioning of the muscular and circulo-respiratory systems. The outcome of these is expressed in forms of strength, muscular endurance, flexibility, balance, agility, stamina and power. He observed that participation in sports leads to the development of these named components of physical fitness which are necessary ingredients for efficient daily functioning and happy living.

Okplenye (2008) also opined that sports participation leads to development of good health, development of body parts and proper bone formation. For instance, some children grow up with malformed bones such as 'knock knee, bow legs' etc. but early exposure to appropriate exercises, sports and diet help to correct such defects. He concluded that the heart is stronger, healthier and pumps blood better, and circulation of blood is faster and smoother because of physical activities.

Without doubt, there is a broader understanding that the distinctive contribution Physical Education andSchool Sports (PESS) makes to a child's education is within the physical domain. The nature of the physical focus of PESS has shifted over time, moving from an initial health-related rationale in the first half of the twentieth century to more performance-related considerations following the Second World War, to concern about the health impact of sedentary behaviours more recently.

\section{CONCLUSION AND RECOMMENDATIONS}

Based on the result of the study the following conclusion was reached. There is a significant difference in the physical variable of secondary school students who participate in sports and those who do not participate. Some recommendations were made:

- Those students in secondary schools should participate in sports to avoid sedentary lifestyle.

- The physical education teachers, who are the custodians of sports in these schools, should make sure that every student takes active part in sports during training sessions.

- Government of Cross River State should endeavour to make Wednesdays to be sports day from 4pm - 6pm to enable the students achieve maximally in sports participation.

\section{REFERENCES}

[1] Aarnold, M., Kujala, U.M., and Kaprio, J. (2007). Associations of health-related behaviors, school type and health status to physical activity patterns in 16 year old boys and girls. Scandinavian Journal of Social Medicine;25:156-167.

[2] Afuekwe, A. I. (1999). An introductory textbook of physical education for secondary schools and colleges.Calabar: Seasprint (Nig.) Co. Ltd.

[3] Agbekuru, M. (2000).Harnessing effective participation in sports. Kaduna, Sule Enterprise.

[4] Agbomi, C. E. (2012). The role of sports in nation building. An unpublished seminar paper in CIINSTRID annual seminar, Calabar

[5] Baumert, W; Henderson, R; Thompson J. (2009). Attraction to physical activity in urban schoolchildren: parental socialization and gender influences, Research Quarterly for Exercise and Sports journal, 67, 316-323.

[6] Edim, M. E., Emeribe, V. C. \&Akah, L. U. (2008). Sports participation: A catalyst in health promotion and quality 
living.ICHPER-SD Africa Regional Congress Proceedings, University of Botswana, (pp.288 - 293) 14 - 17 October.

[7] Edim, M.E. (2011). Sports participation: A medium for health promotion and quality living.Journal of Sports Management and Education Research, 1(1) 51-59.

[8] French, S.A., Perry, C.L., Leon, G.R., and Fulkerson, J.A. (2008). Food preferences, eating patterns, and physical activity among adolescents: correlates of eating disorders symptoms. Journal of Adolescent Health; 15:286-294.

[9] Hans, V. (1999).Teacher Personality traits and characteristics and learning effectiveness of pupils.In C. G Asagwara (Ed).Psychological Perspective.Calabar: Psychological Productions and Services.

[10] Ndu, P. (2007).Physical activity and the initiation of high-risk health behaviors in adolescents.Journal of Medicine and Science in Sport and Exercise;27:1639-1645.

[11] Odigbo, C. I. (2000). Modern physical education. Ibadan: Evans Brothers Publishers Limited.

[12] Okplenye, M. O. (2003). School athletic participation: mostly gain with little pain. Sports and Exercise Psychology journal. 25:205-228.

[13] Oyeniyi, P. O. (2001). Sourcing funds for the effective administration of school sports in Nigeria.Ibadan Codat Publications.

[14] Prasad, C. \&Bannergee, A. M. (1997).Management of human resources.New Delhi; Sterling Publishers private Limited.Sage, K. (2007).Unity and play.Ibadan, Yuji Publishers. 